\title{
RADICAL EMPIRICISM, CRITICAL REALISM, AND AMERICAN FUNCTIONALISM: JAMES AND SELLARS
}

\author{
Gary Hatfield
}

As British and American idealism waned, new realisms displaced them. The common background of these new realisms emphasized the problem of the external world and the mind-body problem, as bequeathed by Reid, Hamilton, and Mill. During this same period, academics on both sides of the Atlantic recognized that the natural sciences were making great strides. Responses varied. In the United States, philosophical response focused particularly on functional psychology and Darwinian adaptedness. This article examines differing versions of that response in William James and Roy Wood Sellars. James viewed the mind as a "fighter for ends." His neutral monism, by taming the mind-body problem and the problem of the external world, provided a secure metaphysics of mind as functional activity. In contrast, Sellars's scientific realism endorsed physical reality but was not mechanistic or reductionist. His critical realism and evolutionary naturalism offered novel metaphysical and epistemological positions in comparison with other American and British realisms. James and Sellars are distinguished from British philosophy in 1890-1918 in the types of realism they endorsed and in their success at introducing Darwinian evolutionary considerations and functional psychology into mainstream philosophy.

\section{New American Realisms}

American philosophy in the decades after the turn of the twentieth century was vital, active, and philosophically diverse. Several positions arose in opposition to the idealism of Josiah Royce and the young John Dewey and its British counterparts. The most noted brand of new American philosophy from this time was Pragmatism, a name often used to characterize the new

Contact Gary Hatfield at Department of Philosophy, University of Pennsylvania, Cohen Hall, Room 433, 249 S. 36th Street, Philadelphia, PA 19104 (hatfield@phil.upenn.edu).

HOPOS: The Journal of the International Society for the History of Philosophy of Science, vol. 5 (Spring 2015). 2152-5188/2015/0501-0002\$10.00. (C) 2015 by the International Society for the History of Philosophy of Science. All rights reserved. Electronically published February 10, 2015. 
tendencies in American philosophy in general. But there were other selfidentified tendencies at this time, including New Realism, Critical Realism, Evolutionary Naturalism, and (American) Functionalism, which ought not to be lumped together under the single rubric of "pragmatism." Putting terminology aside for the moment, we may ask which streams of early twentiethcentury American philosophy "go together" and whether something distinguishes such philosophizing from its European counterparts, other than its being American. For indeed the adherents of Pragmatism and the various "realisms" and "naturalisms" were in dialogue and did see themselves as responding to common problems with some degree of agreement-sometimes quite a bit of agreement and sometimes only a little.

Several things are common among American philosophers such as William James, Dewey, Roy Wood Sellars, F. J. E. Woodbridge, Charles A. Strong, and Ralph Barton Perry. They all shared an interest in science, they all had some interest specifically in psychology, they all were interested in epistemological questions, and they all had an interest in perception. But these commonalities do not distinguish this group from near contemporary European philosophers and philosopher-scientists, including Helmholtz, Wundt, Mach, and Russell. We could add a few other commonalities, such as that they all opposed the idealism of F. H. Bradley or Royce, they all held that knowledge (or the fact or process of knowing) does not change its object, they were all pluralists in the sense of believing that more than one thing exists, they all wanted to avoid representative realism, and they were all interested in the relation between physiology and psychology, or brain and mind. Allowing some latitude in the brand of idealism opposed, then Helmholtz, Wundt, Mach, and Russell (after 1912 for representative realism) all still fit the bill. We might add a further commonality: that they were all friendly toward metaphysics. This would set them apart from Mach and even Helmholtz (although he by no means held metaphysics to be meaningless) but not from Russell or Moore.

In seeking a unifying factor for some group of the Americans-to see whether there is one, not because there must be one-we may consider an interest in Darwinian biology as applied to problems of mind and the attendant (bio-)functionalist conception of mind. In American psychology, the functionalist bent of the Chicago department fueled the "Functionalist" school of psychology, whose founding documents are Dewey (1896) and Angell (1907). ${ }^{1}$ In American philosophy, a strong interest in Darwin and func-

1. On the functionalist school of psychology, see Heidbredder (1933) and Owens and Wagner (1992). In the 1890s, Dewey was known as both philosopher and psychologist. Dewey is also associated 
tionalism sets New Realists and Critical Realists (or major adherents of each) apart from the Helmholtz, Wundt, and Russell. ${ }^{2}$ For although Helmholtz, Wundt, and Russell each acknowledged Darwin in some way, they did not bring him in strongly. Mach tips his hat toward cognitive economy and the adaptation of organisms to environments; however, he does not offer a functional analysis of perception but emphasizes processes of association as the basis for perceptual order. ${ }^{3}$

I believe that it is functionalism, in the biological sense, that unites the Americans. They view mind or mental capacities in a characteristically functional way. ${ }^{4}$ This involved several factors. First, they viewed the whole organism as adapted and adapting to its environment through sensorimotor systems that work together, systems that are the product of evolutionary adaptation to an environment but that also allow for learning in adapting to specific cir-

with Pragmatism, sometimes under the name of "Instrumentalism" (Dewey 1905). During the eighteenth and nineteenth centuries, psychology usually was seen as one of the philosophical disciplines, in a broad sense of "philosophy" that includes natural philosophy. By 1900 in America (as also in Germany), psychology was a recognized scientific discipline, distinct from philosophy (see Hatfield 2002). All the same, the two disciplines enjoyed strong interaction, and some individuals belonged to both, as did Dewey and James.

2. The self-avowed New Realists (Holt et al. 1912) included Edwin B. Holt, Walter T. Marvin, William Pepperrell Montague, Perry, Walter Pitkin, and Edward Gleason Spaulding. Perry (1912, chaps. 12, 13) grouped James with the New Realists, as does Kuklick (2001, 202-3). Among the New Realists, James and Montague (1920-21) show the greatest connection to Darwin's theory and related notions of evolved function (with Holt following up). The self-avowed Critical Realists (Drake 1920) were Durant Drake, Arthur O. Lovejoy (who later jumped ship), James Bissett Pratt, Arthur K. Rogers, George Santayana, Sellars, and Strong. Among them, Sellars, Lovejoy, and Strong show the most interest in Darwin and functionalism. Holt et al. (1912) and Drake (1920) are efforts at "cooperative" philosophy, seeking terminological uniformity (as far as possible) and explicit agreement on some common principles, to allow for cooperative research as in the special sciences (see Holt et al. 1910; Drake 1920, vi-vii; Montague 1937, 142-43). Dewey (1903) is an earlier example of a cooperative approach.

3. Mach $(1897,1976)$ frequently invokes adaptedness and cognitive economy, but in explaining the formation of complexes of elements ("body" and "ego") he appeals to association (1897, 2, 9, 41; $1976,16,23)$ and says little about functionally adapted psychological structures and processes.

4. Woodbridge $(1904,592)$ sees France and America as centers of the application of evolutionary thinking to "logic" (which includes or abuts theory of knowledge). Noting that "in America the union of logic and biology is complicated," he mentions the application of evolutionary thinking to morals and asks: "If morality can be brought under the categories of evolution, why not thinking also? In answer to that question we have the theory that thinking is an adaptation, judgment is instrumental. But I would not leave the impression that this is true of pragmatism alone or that it has been developed only through pragmatic tendencies. It is naturally the result also of the extension of biological philosophy. In the biological conception of logic, we have, then, an interesting coincidence in the results of tendencies differing widely in their genesis" (592). In his own work, Woodbridge (1908, 15) acknowledges biological evolution but places his naturalism in an Aristotelian context and views evolution as historical development (1912), which explains the addition of Hegel to Darwin and Spencer in Woodbridge's lineage of evolutionary thinking $(1904,592)$. 
cumstances. Second, they saw subsystems, such as the visual system, as serving the ends of the larger whole. Third, they stressed activities and processes over static structures. ${ }^{5}$

An appeal to functionally characterized systems and to evolved adaptation does not separate this subgroup of Americans from Spencer and the English Darwinians of the latter nineteenth century, including G. H. Lewes among the more philosophically inclined. Evolutionary thinking as applied to mind and psychology blossomed in the latter nineteenth century in both Britain and America. Many of the adherents were scientific intellectuals or scienceoriented philosophers, often without university appointment. The latter group includes Spencer, Lewes, T. H. Huxley, George Romanes, and, in the United States, James's early mentor Chauncey Wright. ${ }^{6}$ In Britain, C. Lloyd Morgan applied Darwin to mind in the nineteenth century, but he did this more within psychology than in connection with epistemology or a theory of perception. ${ }^{7}$ A significant difference between these nineteenth-century intellectuals (British and American) and James and Sellars is that the latter two (along with Dewey) brought functional and evolutionary perspectives into academic philosophy. ${ }^{8}$ Sellars's evolutionary outlook was part of a general philosophical

5. These three factors emerge from Ruckmich's (1913) analysis of the term "function" as used in textbooks of psychology, as supplemented by Dewey (1884, 1896), James (1890), and Angell (1907). In Sellars $(1907,1920)$, the first and third factors are most prominent. Of course, I am not asserting that these three factors convey the full content of "functionalist" discussions of an integrated organism or the role of evolution; Dewey (1910, "Influence"), e.g., finds evolution important philosophically for emphasizing becoming over being.

6. On the early reception of Darwin among Cambridge intellectuals, including Wright (a strong adherent for Darwin over Spencer), Peirce, James, and John Fiske, see Wiener (1949) and Menand (2001). On evolutionary theories of mind and behavior more generally in nineteenth-century Britain and America, see Richards (1987).

7. It's not that Morgan did not have specifically philosophical interests, but his discussions of perception and the problem of the external world come late and reference Sellars: Morgan (1923), chaps. 7-8 and appendix; the latter cites Sellars's (1922) “critical realism.” Morgan's philosophical works extending British Darwinism postdate the American efforts.

8. On the British side, L. T. Hobhouse (1901) and Samuel Alexander (1920) are partial exceptions, although Hobhouse's evolutionism was not greatly noticed in British academic philosophy, and Alexander's evolutionism was not Darwinian or particularly biological. Hobhouse wrote Mind in Evolution (1901) while working for the Manchester Guardian. He had taught philosophy as a fellow of Corpus Christi in Oxford until 1897, producing an epistemological work (Hobhouse 1896). His interests turned toward sociology, and in 1907 he became professor of sociology at the University of London (although retaining relations to philosophy). His 1901 book received much of its notice from psychologists. The same can be said for his Development and Purpose (1913), which attracted some philosophical attention in America (e.g., Perry 1917); in Britain, it received a moderately negative review from Bosanquet (1913). Hobhouse's Morals in Evolution (1906) attracted philosophical attention in both Britain and America, largely negative in the former (e.g., Seth 1908). Alexander (1920) proposed a philosophy of emergent evolution, using the latter term to mean development and considering the emergence of properties (or "qualities") of life and mind from physicochemical processes; 
system of Critical Realism and Evolutionary Naturalism. James invoked Darwin most explicitly in his psychology but relied on his functionalist interpretation of consciousness in his radical empiricism to do away with the notion of the subject and be left with an ontology of metaphysically minimalist "stuff." Subsequent sections fill out these characterizations of James and Sellars.

For now, I want to approach what they have in common from another direction, by characterizing a complex of philosophical issues and agreed-on diagnoses that set a common framework for philosophy in both America and Britain. This framework comes partly from a shared conception of what had gone wrong in philosophy from Descartes to Hume and partly from a nexus of philosophical issues arising with increased activity in psychology and neurophysiology. Some of the Americans gave distinctive answers to epistemological and metaphysical questions they shared with their transatlantic colleagues. Accordingly, James and Sellars set themselves apart from the Europeans and from each other by combining distinctive epistemological and metaphysical positions with their functionalism and evolutionary thinking. The next section lays out a common Anglo-American problem and solution space in epistemology and metaphysics; I subsequently turn to the distinctive positions of James and Sellars. ${ }^{9}$

\section{Common Problems from a Shared Background}

The "new" Anglo-American philosophies that arose circa 1900 agreed in being in some sense realist. This realism was in the first instance set in opposition to idealism, which included German Idealism, British Idealism, and the idealism of Royce. A common characteristic of these idealisms was that the world is an embodiment or expression of reason or mind. This idealism was taken to be monistic: it posits that there is only one thing, the Absolute. In-

there is not a strong element of Darwinian evolution in his work. Cunningham (1996, chaps. 2-3) details Moore's and Russell's cold responses to the philosophical relevance of Darwin.

9. In his insightful comments on an early draft of this article, Alex Klein asked in what sense James and Sellars may be classed as a group. Specifically, he wondered whether they form a self-avowed grouping, an external historical grouping (such as we impose on the British empiricists), or a developing lineage with common sources. In any case, James, Dewey, Angell, and Sellars form a selfavowed lineage (Sellars [1907, 17] refers to Angell on functional psychology and to Strong on evolution; Dewey [1903, preface] sees a debt to James and an endorsement of functional psychology as shared by the cooperating authors of the book); the lineage favors natural selection over Lamarckism and, hence, extends back to Darwin and may include the English Darwinians of the latter nineteenth century. The Americans remain distinctive in their versions of Realism, New and Critical (offering different answers to a common problematic) and in their priority in bringing evolutionary thinking into mainstream philosophy. 
dividual minds are limitations on the Absolute. The objects of knowledge are mind dependent and are altered or constituted through being known.

The realists who opposed this idealism included, prominently, Moore and Russell after 1898, James from about the same time, the New Realists who followed James, Woodbridge, and Sellars and (many of) his Critical Realists. These anti-idealists rejected the mind dependence of the object of knowledge, its mental nature, and the conditioning of the object in being known, and they affirmed a plurality of things_ — although not necessarily of kinds of things - in opposition to the monism of the Absolute. ${ }^{10}$

Seeing these authors as all rejecting the idealism of their predecessors, or of their own youths, sheds light on the positions of figures such as Moore and Russell. The realization that mind independence could be the criterion of the real helps make sense of how Russell's middle-period sense-data philosophy, in which he rejects the existence of material things in the usual sensethat is, of material things considered as made of garden variety matter-could still be considered a realism. And it helps make sense of how James's neutral monism - the name given his position by Russell — which gives up both ordinary material things and the subject of the mental acts allegedly directed on them, could be called a new realism. Both are realisms without material reality. James's entities, characterized more closely below, are "real" because they are mind independent. They are many and can exist and be known in independence of one another. This is a "pluralistic" realism of many independent things (which may all be of one "neutral" kind) set over against an idealistic monism of one all-encompassing Absolute.

Although recognition of the opposition of the new realisms to idealism is illuminating, it does not fully reveal the archaeology of the new British and American philosophies circa 1900. A deeper conditioning factor, shared with idealists, shapes the space in which innovators developed their philosophical positions. This factor is the problem of the external world. In the decades surrounding the turn of the twentieth century, the problem of the external world was the fundamental problem of philosophy for the groups we are considering. It provided a framework for a nest of other problems, anent epistemology, ontology, and the mind-body relation.

This problem of the external world was not primarily the problem of whether or how we know the external world, of avoiding skepticism. That

10. To see how idealism was understood by its youthful friends-turned-foe and other opponents, consult Perry (1912), pt. 3, and Russell (1912, chaps. 5 and 9; 1959, chaps. 4 and 5). Descriptions of idealism by its opponents may not be accurate: see Horstmann (1984) and Candlish (2007). 
was the classic problem of knowledge from Descartes to Hume. It was generally accepted that Hume's radical skepticism—on a standard skeptical reading of his philosophy — was a reductio of the problem of knowledge inherited from Descartes and Locke. This diagnosis of the shape of the history of the problem was given by Thomas Reid and accepted by basically all parties among the new realists. Reid's philosophy, as interpreted and conveyed by William Hamilton and, for the Americans, by Dugald Stewart and James $\mathrm{McCosh}$, set the problem space for turn-of-the-century Anglo-American philosophy. ${ }^{11}$

Hamilton's Lectures on Metaphysics, published posthumously (1861), and his edition of the works of Thomas Reid (1846), with numerous discussion notes and appendixes, were central works of philosophical discussion in the middle decades of the nineteenth century. Mill's Examination of Sir William Hamilton's Philosophy (1872) stirred up a flurry of response, and, although it cut into Hamilton's popularity, it did not immediately remove Hamilton's works from prominent reading lists in philosophy, including the reading list for the Cambridge Tripos in moral philosophy (e.g., Cambridge University 1893, xvii).

In his lectures, and an earlier paper in the Edinburgh Review, republished in his collected Discussions (1855), Hamilton laid out the space of positions on the problem of the external world and the perceiver's relation to the object, including the ontology or metaphysics of perceiver and object. As constructed from Hamilton's list $(1855,61)$, these are

(1) Natural Realism or Natural Dualism, according to which we have "intuitive knowledge," or direct apprehension without intermediary, of both mind (through its acts) and matter (through its properties), and are accordingly assured the existence of both (a commitment to mind-matter dualism);

(2) Absolute Identity, which "reduces mind and matter to phenomenal manifestations of the same substance" [the position of Spinoza];

(3) Idealism (as in Berkeley);

(4) Materialism;

(5) Nihilism, in which "consciousness itself" is "recognized only as a phenomenon, and the substantial reality of both subject and object denied" (the position ascribed to Hume); and finally the position, according to Hamilton, most prevalent before his time:

11. On the background to the problem of the external world before and including Russell, see Hatfield (2013b). On Scottish philosophy in North America, see Foster (2012). 
(6) Cosmothetic Idealism, Hypothetical Realism, or Hypothetical Dualism, ${ }^{12}$ which regards "the object of consciousness in perception as only a modification of the percipient subject, or, at least, a phenomenon numerically distinct from the object it represents."

Number 6, otherwise known as "representative realism," Hamilton further divided into three versions, depending on the relation of the representative object to the mind $(1855,63)$ :

(6a) "The representative object not a modification of mind." This broad category describes positions that posit a representative object distinct from the mind and from external objects; it both comprises Malebranche's vision in God and prospectively fits the sensedata theories of Moore and Russell;

(6b) "The representative object a modification of mind, dependent for its apprehension, but not for its existence, on the act of consciousness." The representative object is a mental state that may exist outside consciousness (the mental act of apprehension is distinct from the mental content apprehended), a position that Hamilton and Reid found in the theory of ideas of Descartes and Locke; and

(6c) "The representative object a modification of mind, non-existent out of consciousness; - the idea and its perception only different relations of an act (state) really identical." There is no difference between mental act and object; the mental state is a perceiving, characterized by a representational content. Hamilton ascribed this position to Thomas Brown.

Hamilton supported 1 and sought to undermine 6. He did not give much play to positions $2-5$.

Our realists from the turn of the century also focused on 1 and 6. Dual aspect monism (2) was in play (e.g., Lewes 1874-79) but not among our group. Idealism (3) was the enemy to be rejected. Materialism (4) was largely a nonstarter, although Sellars adopted a related position of physical realism. Nihilism, or Humean skepticism, was taken as a reductio of 6. Position 6, or rep-

12. "Cosmothetic Idealism" is the same position as Hypothetic Realism and Hypothetic Dualism. It is "idealism" in the sense in which Reid $(1997,23)$ described Descartes and Locke as adherents of "the ideal system": according to him, they ascribed to the theory that ideas are the immediate objects of perception. They are representative realists and mind-body dualists; the other two labels are to be understood accordingly. 
resentative realism, was held for a time by Russell (until late 1912), was one of the favored positions of Moore, but was regarded as obviously untenable by our American realists.

The lesson that our American realists learned, as if by distant echo, from Reid and Hamilton, was the diagnosis of the inevitable failure of representative realism. That is, they accepted Reid's diagnosis that the theory of ideas as ascribed to Descartes and Locke-according to which ideas as mental states are the immediate objects of sensory perception-is doomed to lead inevitably to Berkeleian idealism and on to the utter despair of (the skeptical) Hume.

In an address before the International Congress of Arts and Science at the Universal Exposition in St. Louis of 1904, Woodbridge echoed this diagnosis: "Locke's axiom that 'the mind, in all its thoughts and reasonings, hath no other immediate object but its own ideas,' an axiom which Kant did so much to sanctify, and which has been the basal principle of the greater part of modern logic and metaphysics, is most certainly subversive of logical theory. The transition from ideas to anything else is rendered impossible by it" (1904, 597). Because this transition, also known as the "transcendent" jump, was rendered impossible by Locke's position, his theory of ideas was considered to be obviously defective. In practice, knowledge is found to be possible. So a theory of perception and its objects must be found that shows it as possible. James gave this same diagnosis in Radical Empiricism (1912), rejecting the notion of experience as "representative" in a "quasi-miraculous 'epistemological' sense" (61), speaking of the "epistemological chasm" of the transcendentalist (67), and denying, with Berkeley, the validity of a position commonly ascribed to Locke, according to which sensations are "copies" of the external world (212).

Sellars also regarded the problem of the perception of the external world as fundamental. Looking back retrospectively in 1969 to American philosophy at the beginning of that century, he noted that philosophy had been reinvigorated by the then recent progress in science, including physics, biology, and psychology. He did not see science as a threat to philosophy but as an impetus toward new work. Nor did he think that the scientists themselves could complete this new philosophical work. As he put it:

This [the progress in science] did not mean that, when confronted by the general problems philosophy and religion had raised, the scientist would offhand have an answer for them. I had read my Huxley and my Tyndall and saw where they diverged. My sympathies were more with Tyndall but I saw that Huxley was aware of the problems connected 
with the mind-body issue. These were inherited epistemological questions connected with Locke, Berkeley and Hume and with Cartesian dualism and had to be met. As time went on, I focused my attention on perceiving as the starting-point of knowing, on the mind-body problem, and on the import of evolution. These, I felt, were tied in together. (Sellars 1969, 3-4)

Sellars here affirms that the problem of knowledge starts from perception. In a survey of epistemology composed early in the new century, he rejected all previous theories of knowledge, including that of James. As regards the "representative view," Sellars accused it of "a duplication of the cognitive object” $(1912,227)$. It makes a mental item the immediate object of knowledge and that from which the transcendent object is to be known. In its "duplication of the cognitive object as idea and as object," it renders "unthinkable" the "transcendence of mind" needed to reach the real but independent object of knowledge, thereby limiting cognition to a "personal system of ideas" (230).

In the accepted problem space concerning perception of the external world, a contending philosophical position must give accounts of the ontology of perception, the relation between consciousness and perception, and the immediate object of perception. Hamilton held that we directly experience both mind and matter in perception, that we are aware of their existence, and that we know (some of) their properties. Many authors did not accept his intuitive realism because of the argument from perceptual variability, by which Russell and Moore sought to establish sense data, and its close counterpart, the argument from physiological or psychological conditioning of perceptual experience, which rendered naive realism untenable. ${ }^{13}$ However, these arguments were not why James differed from Hamilton. In a way, James accepted Hamilton's position that the objects of perception are directly present in experience, but his position was ontologically austere in banishing mind and matter as distinct kinds of stuff and settling on neutral items as the immediate objects of perception (in a manner to be explained). James's position was not on Hamilton's list.

Sellars took an opposite tack. He rejected intuitive positions such as Hamilton's as incompatible with his physical realism about the organism and its perceptual apparatus. Taken one way, he developed a new variant of Hamilton's position 6 in which the act of perception, its mental content, and the external object are distinct. However, since for Sellars the mental content is not

13. On theories of sense data in the first decades of the twentieth century, see Hatfield (2013a). 
the object of perception but the means by which an external object is affirmed, it is better to say that his position also is off the list, since it amounts to a mediated but direct realism.

In developing their novel responses to the problem of the external worldnovel both as regards the ontology of perception and the relation between perception and object-James and Sellars faced problems along another dimension of Hamilton's classificatory scheme, concerning the relation between mind and matter. Hamilton adopted dualism with 1 , in which mind directly intuits matter. He ascribed a dualist position to adherents of 6 , and this ascription fits Locke, the Russell of Problems (a dualism of mental act and material object), and Moore in some moods. These dualisms came along with the usual problem: How do mind and matter influence one another?

In his Principles of Psychology, James reviewed conceptions of the mindbrain or psychology-physiology relation. He rejected the epiphenomenalism then popular in England (espoused, e.g., by Clifford [1874] and Huxley [1874]) as denying the functional efficacy of mind. He rejected the psychic atomism of associationism because he found it to be unworkable as an explanatory framework. He put off the "monadism" of Lotze as too remote from scientific evidence. James recognized that the "ultimate of ultimate problems . . . in the study of the relations of thought and brain, is to understand why and how such disparate things are connected at all" (1890, 1:177). Despite unresolved metaphysical difficulties, in the Principles James endorsed the "soul" theory as the least objectionable: "I confess, therefore, that to posit a soul influenced in some mysterious way by the brain-states and responding to them by conscious affections of its own, seems to me the line of least logical resistance, so far as we yet have attained" (1:181). For the purposes of psychology, he accepted an "empirical parallelism." In the next section, we consider his attitude qua metaphysician.

Unlike James, ${ }^{14}$ Sellars was in no sense a practicing (or at least teaching and theorizing) scientist. He was a philosopher through and through. But he considered his philosophical position and indeed the philosophical problematic of his age to be deeply conditioned by the recent successes of the sciences. A new philosophy was needed and made possible by the new results of science. This new situation allowed for the development of a more satisfactory naturalism. The old naturalism, in attempting to overreach what it could obtain, gave sustenance to enemy philosophies. As Sellars later put it, "It was because atomistic, mechanical materialism found itself unable to do

14. Speaking of the Metaphysical Club, which met in Cambridge during the 1870s, Peirce said (ca. 1906) that "Wright, James, and I were men of science" (quoted in Wiener 1949, 19). 
justice to man's world that dualism and idealism so long dominated thought" $(1932,4)$. In rejecting mind-matter dualism and idealism, he sought to develop an evolutionary and critical naturalism, a naturalism that yielded a more robust realism than the neutral monism of James and the New American Realists.

Despite their fundamental differences, James and Sellars were both guided by an attitude that was, in the first 2 decades of the twentieth century, characteristically American. ${ }^{15}$ They approached perception as the biological function of an adapted and adapting organism. ${ }^{16}$ Let us see how.

\section{James and the One "Stuff"}

In the Principles, James adopted a provisional empirical, conceptual, and methodological dualism, which distinguished subject and object-a position he adopted qua psychologist: "The psychologist's attitude towards cognition will be so important in the sequel that we must not leave it until it is made perfectly clear. It is a thoroughgoing dualism. It supposes two elements, mind knowing and thing known, and treats them as irreducible. Neither gets out of itself or into the other, neither in any way is the other, neither makes the other" (James 1890, 1:218). His methodological and conceptual "dualism" analyzes what is involved in psychological acts of cognition and is a presupposition of a natural scientific psychology (1:vi). The full set of assumptions

15. Above I acknowledged that an evolutionary, functionalist psychology was actively discussed in Britain before the turn of the twentieth century. The works of Romanes and the activity of Morgan were extant as the twentieth century began, as were the works of Hobhouse, but they drew ever less attention in British philosophy. As already noted, Russell saw no special relevance of Darwin for philosophy. Otherwise, after some struggle, Russell ultimately accepted James's neutral monism, but only a little before 1920 .

16. In the latter half of the nineteenth century, the term "adaptation to the environment" was used with differing connotations. The basic meaning in biology and psychology is that an organism's capacities (including anything from structures to innate functions to acquired habits and ideas) are adjusted to its circumstances. The mechanism of adjustment was under dispute, including as candidates divine design, evolution through inheritance of acquired characteristics, or Darwinian natural selection. Darwin spoke frequently of adaptation through natural selection (e.g., 1859, 82). James accepted the principle of natural selection through accidental variation of hereditary traits and differential survival and recognized it as one of two ways in which "zoological evolution" might allow that "an animal race may grow to be a better match for its environment" (1890, 2:626). In James's terminology, the other way was Spencerian "adaptation" via hereditary acquired characteristics. James favored natural selection from the first $(1878,14)$ and in the Principles explicitly rejected Lamarckism (1890, 2:678-88). Leaving his word usage aside, James recognized Darwinian natural selection as adjusting or adapting organisms to their environments and included instincts and (at least some) mental functions in that purview. Sellars (1922, chap. 15) accepted Darwinian natural selection but held open the possibility that biologists might discover yet other mechanisms beyond design and creative life tendencies (both of which he rejected). 
includes four things: the psychologist, the psychologist's reality (brains, objects), the thought had by the psychologist's subject, and the object of that thought from the subject's point of view. In the Principles, James did not advance this dualism as a metaphysical hypothesis, consonant with treating psychology as a natural science and keeping his book as free as possible from metaphysics. ${ }^{17}$ This psychological dualism avowedly is consistent with nondualistic metaphysical hypotheses about the mind-brain relation.

According to this methodological and conceptual dualism, the mind constructs the object of knowledge as a result of stimulation to the nervous system. James calls such stimulation a "signal" from the thing: "Some sort of signal must be given by the thing to the mind's brain, or the knowing will not occur-we find as a matter of fact that the mere existence of the thing outside the brain is not a sufficient cause for our knowing it: it must strike the brain in some way, as well as be there, to be known. But the brain being struck, the knowledge is constituted by a new construction that occurs altogether in the mind. The thing remains the same whether known or not" (1890, $1: 219)$. For all the psychologist knows, this occurring "in" the mind might be an occurring as a mental act of the brain. Without adopting this position himself, James averred: "The dualism of Subject and Object and their preestablished harmony are what the psychologist as such must assume, whatever ulterior monistic philosophy he may, as an individual who has the right to be a metaphysician, have in reserve" (1:220). The "pre-established harmony" is not that of Leibniz and monads but is functional: the nervous signals, which are in no way "pictures" of external things, are interpreted by a mind that can produce thoughts that correspond to and provide knowledge of the external object. The psychologist assumes knowledge to be possible and does not attempt to cover all epistemological concerns (1:184). Finally, in the quotation above James ascribes realism about external objects to the psychologist: "The thing remains the same whether known or not." The existence of things is not dependent on our perceiving them.

James regarded the brain-mind system as evolved and adapted. The system exhibits appropriateness of behavior to serve the ends of the organism. In seeking to characterize consciousness, he described it as "a fighter for ends" $(1890,1: 141)$. The mark of intelligence comes in the selection of means to achieve ends (1:8). But the brain-mind system has additional functional or-

17. James was not opposed to metaphysics, only to half-baked metaphysical ideas: "Metaphysics fragmentary, irresponsible, and half-awake, and unconscious that she is metaphysical, spoils two good things when she injects herself into a natural science" (1890, 1:vi). Fully awake metaphysics can properly discuss the elements of psychology, such as the distinction between mental act and object described above, and its status (vi), but it does so as metaphysics. 
ganization that does not depend on consciousness or having the ends actually in view. It is organized to produce (on the whole) biologically appropriate behaviors in response to circumstances. James called these adjusted mechanisms instincts and emotions. With an instinct, the animal need not have the end in view consciously or cognitively (2:383). But it must possess behavioral patterns that are triggered by circumstances for which those behaviors are appropriate. Sucking is a human oral instinct, present from birth (2:404).

In James's scheme, the organs of the brain evolve, just as do other organs. As one proceeds up the scale of being, behaviors that require close adjustment to varying circumstances become the province of the "higher" (cerebral) brain centers, whereas stereotypical behavioral repertoires become instinctual. In a flirtation with a kind of animal organic panpsychism, James held that "all the [nervous] centres, in all animals, whilst they are in one aspect mechanisms, probably are, or at least once were, organs of consciousness in another, although the consciousness is doubtless much more developed in the hemispheres than it is anywhere else" (1890, 1:78). Living animal matter may well be characterized by a kind of sensation and desire, which in its primitive state provides the material on which evolution acts:

All nervous centres have then in the first instance one essential function, that of "intelligent" action. They feel, prefer one thing to another, and have "ends." Like all other organs, however, they evolve from ancestor to descendant, and their evolution takes two directions, the lower centres passing downwards into more unhesitating automatism, and the higher ones upwards into larger intellectuality. Thus it may happen that those functions which can safely grow uniform and fatal become least accompanied by mind, and that their organ, the spinal cord, becomes a more and more soulless machine; whilst on the contrary those functions which it benefits the animal to have adapted to delicate environing variations pass more and more to the hemispheres, whose anatomical structure and attendant consciousness grow more and more elaborate as zoological evolution proceeds. (1890, 1:79)

This passage confirms James's view that evolution encompasses both instinctual reflex-like mechanisms and the organic basis of thinking and learning, the latter being functions that allow delicate adaptation to varying circumstances. That is, the ability for deliberation depends on evolved functions that support learned and creatively produced responses to novel situations. In a footnote to the sentence containing the word "evolution," James remarks that there are two theories of evolution, "inheritance of habits acquired" or "pres- 
ervation of lucky variations." He defers a choice between them to the last chapter of the book, where he declares his allegiance to Darwinian natural selection over Spencerian inheritance of acquired characteristics. ${ }^{18}$

Fourteen years after the publication of the Principles, James presented his mature metaphysics to the world in a series of essays, and he continued to elaborate it until his death. ${ }^{19}$ The metaphysics is a "radical empiricism" (as James [1904] called it) or "neutral monism" (as Russell [1914] named it). By comparison with ontological dualism, it posits "one primal stuff or material in the world, a stuff of which everything is composed" (James 1912, 4). James calls that stuff "pure experience," which, for purposes of illustration, may be equated with an occurrent presentation. He invites his reader to "begin with a perceptual experience, the 'presentation,' so called, of a physical object, his actual field of vision, the room he sits in, with the book he is reading as its center" (11). This experience can be considered under two attitudes: as an object of knowledge in the world, which might be known by other people, and as an occurrent state of mind, a present experience. James's radical thesis is that the world consists only of such "stuff"; he interprets the notions of subject and object as ways of collecting this stuff. Collect the sequence of views of the room over time, whether anyone is there to see them or not, and one has the object; collect the sequence of experiences from the vantage point of an individual person, and one has the subject. In each case, all there is to the subject or object is a specific collection of "pure experiences"-including the relations among the items in each collection.

James analyzes knowing as a relation between bits of pure experience: "knowing," he says, "can easily be explained as a particular relation towards one another into which portions of pure experience may enter" $(1912,4)$. The "thought" itself becomes the thinker (James 1890, 1:369). ${ }^{20}$ My experi-

18. Of course, Darwin $(1859,209)$ also allowed for the inheritance of acquired characteristics. But in discussions in the latter decades of the nineteenth century, the Darwinian theory of natural selection on unmodifiable and heritable variations was regarded as his distinctive contribution, leaving Lamarckism as Spencer's leading evolutionary theoretical tool. We may further note that James's statement that "all organs evolve" should not be assimilated to a view that every aspect of an animal's organic structure has been produced by natural selection. As far as I know, he did not consider this question explicitly, but we may suppose that he believed that the major adaptive aspects of physiological and psychological organs are evolved.

19. The canonical statements of James's radical empiricism occur in essays published in the Journal of Philosophy in 1904-5. These and some additional essavs are collected in James (1912), with a preface by Perry describing their place in James's philosophical oeuvre.

20. Although James sought to remain metaphysically neutral in his 1890 book, aspects of his account of the stream of thought and of his analysis of consciousness of self carried over into his metaphysics of neutral monism. The idea behind thought as thinker is that the act-object relation 
enced vantage point located in my body behind my eyes is in relation to an experience of the desk and book. This relation is included within experience as an apprehension of an object. It is the relation of knowing. James's theory is a presentational theory, a cousin to Hamilton's intuitive theory, except the relation of intuition has been incorporated into a neutral monist ontology of primal stuff. ${ }^{21}$

By 1909, James viewed this "radical empiricism" as more fundamental than pragmatism in his philosophical oeuvre; pragmatism was preparatory for radical empiricism (1909, xii). Pragmatic notions important for radical empiricism include that "ideas" are guides to action and truth is instantiated in functionally effective action. His example of the idea of Memorial Hall as guiding his walk toward that location and informing him of his arrival (by his having the expected chain of experiences, terminating in a view of the hall) is a case in point (James 1912, 55, 68). Although not worked out in great detail (here or anywhere else that I have found), his idea seems to be that the content of thought is manifested in the difference that the content makes for action and action is resolved into sequences of presentations.

It is here that biology enters into James's metaphysical analysis. Recall that, in the Principles, he treated consciousness as a "fighter for ends" (1890, 1:141). It was not defined by its substantiality but by its functional efficacy as a subjective agency. A leading idea in the radical empiricism (or neutral monism) of 1904 is that agency can be analyzed away into a set of relations and regularities within and between portions of the primal stuff. The subject as agent can be resolved into a set of "external relations." Consciousness is now defined not as an entity or as the activity of a substantial mind or brain but as a function for selecting and guiding action that manifests itself among the neutral elements. The minimalist ontology of neutral monism extricates the functional role of consciousness from the metaphysical conundrums of subject needing to meet object and mind needing to influence brain. To repeat: subject and object are patterns of relations within the neutral stuff; the activity of mind is just a subset of those relations. James's functionalism does not determine his neutral monism; rather, it sets a conceptual framework within

should be understood not as an invocation of two distinct types of thing (a mental act and, in external perception, a physical object) but as a relation between two things of the same kind (two thoughts), one of which reveals a momentary aspect of an object. In neutral monism, there is no object beyond the set of perceived or unperceived neutral bits of "stuff," and the act-object or knowing relation becomes a relation of awareness obtaining between one bit of stuff and another.

21. As James (1912) acknowledges, ultimately this stuff has only time, space, and being in common. His position is pluralistic in holding not only that more than one thing exists but also that the things are constituted just of their properties (26-27). 
which neutral monism appears to be a position that makes his functionalism work metaphysically, by addressing some known problems.

Finally, I should mention that, although James's radical empiricism has been compared with Mach's (1897) similar resolution of subject and object, or mind and body, into "sensations" or "elements," there is an important difference. Mach, although not as dogmatically antimetaphysical as sometimes portrayed, was not offering his analysis of sensations as a fundamental metaphysics. His position is epistemological. ${ }^{22} \mathrm{He}$ is telling us what we can know of self and body: we can know patterns and groupings of elements that are modeled on sensations. James, by contrast, is offering a fundamental metaphysics. He is giving us a theory of what there is and what there is not. And he does so unashamedly.

\section{Sellars's Critical Realism}

Sellars took a circuitous route into philosophy. As an undergraduate, he attended the University of Michigan from 1899 to 1903. In his sophomore year, he was introduced to philosophy and pursued its study, together with "a large range of subjects" (Sellars 1969, 2). Finding that philosophy was not a possible "major" in graduate school, upon graduation he spent a year at the Hartford Theological Seminary. In 1904 he visited Wisconsin in philosophy, supported by a teaching fellowship, studying with F. C. Sharp and Boyd Bode. He returned to Michigan in 1905, where he spent the rest of his career. Summer 1906 found him in Chicago, studying with the philosopherpsychologist James Mark Baldwin. In 1909 he visited France and spoke at length with Emile Bergson, broaching his nascent evolutionary naturalism and advancing emergentism as an alternative to Bergson's vitalism. Bergson sent him on to study with the evolutionary vitalist Hans Driesch in Heidelberg (Warren 1970, xviii). Sellars acknowledged the criticism of bare mechanism by the vitalists but retained his emergentism as a form of physicalism in which living things gain new organic properties through a novel organization of matter.

Recall that Sellars was responsive to the fact that, when he entered philosophy, the intellectual scene was marked by the vitality of natural science. He retrospectively observed that "American philosophy, as it developed in the twentieth century, as the universities got under way, had more intimate con-

22. Banks (2003) mitigates Mach's antimetaphysical position and also correctly observes (247) that Mach may have slipped into metaphysics more than he intended or admitted. Banks's discussion perhaps does not fully capture the sense in which James's and Russell's intentions were avowedly both metaphysical and epistemological while Mach's analysis was avowedly epistemological. 
tact with science than did British philosophy or German philosophy" (Sellars $1969,5) .{ }^{23}$ In his view, American philosophy developed character and strength through this contact, which waned as the succeeding generation first followed the debate between Oxford and Cambridge and then felt the impact of Wittgenstein and Carnap, who tended to "ignore philosophical dialogue and go off on a tangent of their own" (5). Sellars himself responded to the early situation by developing a new form of nonmechanistic naturalism and physicalism.

With respect to the British focus of his younger colleagues, Sellars wrote: "since I could not agree with Russell or Moore on fundamental points . . . it seemed to me that the so-called analytic philosophy which got quite a vogue was ambivalent. In one sense, I liked its emphasis. In another sense, it did not seem to me very creative in either epistemology or ontology. American addiction to it and disregard of its own momentum struck me as a form of neocolonialism" $(1969,5)$. No doubt Sellars liked the emphasis of Moore and Russell because they did not ignore or brush aside the problem of perception, as he thought Wittgenstein and Carnap had done in favor of logic and semantics (3). But he found Moore and Russell's solutions uncreative, or perhaps conventional, because they accepted a shared tenet of idealism and Hamiltonian intuitive realism that knowledge "is the actual presence of reals" known by "presentation" or "intuition" (Sellars 1912, 225; also, 1917, 679). Sellars rejected any theory of knowledge that required the external world as object of knowledge to be intuitively present to the knower, just as he rejected any representative theory that made an internal object or a third thing into an intuited object of perception and hence the object of knowledge.

Sellars's philosophy begins with the presumption that individuals know things, that there is knowledge to be found in science and in everyday life. Everyday knowledge leads toward a kind of naive realism in which the object purportedly is directly and intuitively known. A tincture of science undermines this view and leads to the conclusion that knowledge of the external world is mediated by sense organs, neurophysiology, and mental content.

23. When an earlier version of this article was given at the Bay Area Workshop on Pragmatism in the Philosophy of Science, an audience member questioned whether American philosophy before the logical empiricist immigration really had much contact with science, revealingly posing the question in terms of philosophical engagement with mathematics and physics. Of course, the sciences I am discussing are biology and psychology, and in the first decades of the twentieth century there was a rich pattern of interaction involving James, Dewey, Sellars, E. A. Singer, Holt, Perry, and others (see Hatfield 2002). For philosophy of physics and history and philosophy of physics in the teens and twenties in America, one should look to Morris Cohen (1918) and the important dissertation and book of E. A. Burtt (1925). In any case, contact with biology or psychology must also count as contact with science. 
Sellars's philosophy is naturalistic but critical. It is not naive. Here are his remarks on how epistemology should proceed:

What, then, is epistemology? It is the reflective science which studies the nature, conditions, and development of human knowledge in the light of the available facts. It begins with a reflective study of the individual's field of experience, his distinctions and views of knowledge, and passes gradually to an hypothesis which will best harmonize the known facts. Approaching epistemology in this manner, I have been led to raise myself from the level of natural realism to that of critical realism. The result has been a view of knowledge which meets the demands of modern science and fits in with a flexible naturalism. $(1917,680)$

His view of modern science is not the old mechanistic view, which had no place for human experience. Rather, it is a dynamic view of an organism that adjusts itself to its environment and knows that environment through the mental content that its senses have evolved to provide.

In the philosophy of perception as related to epistemology and the mindbody problem, Sellars developed a new position, not found in Hamilton's scheme. His critical realism took a novel stand on the relations among what is given to consciousness, what is the object of perception, and what is the ontology of the subject. His points about the given and the object of knowledge are set out in a passage in which he contrasts his Critical Realism with the earlier New Realism: ${ }^{24}$ "Now the very gist of the difference between neorealism and critical realism is that the knowledge-content, or object of awareness, is, for the latter, numerically distinct from the existent or object of knowledge. The only justification of the phrase epistemological dualism resides in this fact. The existent acknowledged, but not given, is the object of knowledge, while the mental content given is the material and content of knowledge, but not the object" (Sellars 1918, 507).

First, Sellars sets his position up as an epistemological dualism. It distinguishes the knower and the act of knowing, as well as the mental content of knowing, from the known. But in this regard, it is not an intuitive or a presentational theory. He rejects Lockean representative realism, as well. The experienced datum is mental, and it is given, but it is not the object of perception or knowledge. For sensory knowledge, the object is the external physical object, which is known and affirmed by means of the mental content. The

24. Sellars $(1969,49)$ portrayed James as a precursor to the New Realism; the New Realists viewed James as their inspiration. 
"affirming" of the object is an active and "almost automatic" (Sellars 1920, 198) contribution of the perceiver, in response to dynamic changes in sensory experience that are consistent with an external object of a certain size, shape, and color $(1920,196,202 ; 1961)$. Sellars has proposed a mediated but direct realism. It is mediated in the sense that mental content is the means by which the external object is known and affirmed; it is immediate in the sense that not the mental content but the object perceived through the mental content is the immediate object of perception $(1920,194)$. The content is a perceiving, not (in the primary instance) a perceived..$^{25}$

This attitude toward perception was sustained by Sellars's emergent evolutionism. His aim was to see mental functioning as a product of the physical organism. To achieve this, he had to reconceive the physical organism as more than a mere mechanical device; he needed to view the organism as the product of a creative synthesis effected by evolutionary processes. The organism was an experiencer and a knower. It gained these abilities through its biological development. These abilities could not, in Sellars's view, be accounted for in a reductionistic way. Sellars was a physicalist, but he was not a reductive materialist or reductive physicalist. Life and mind are physical but not narrowly mechanical processes. They are evolved organic capacities.

In his Evolutionary Naturalism of 1922, Sellars explained what he found lacking in past naturalism:

Aside from its philosophical immaturity, past naturalism had three main weaknesses. . . . [It] sought too blindly to reduce or disintegrate, as though novelty could not arise, as though the organic could be only the inorganic. It was dominated almost entirely by the exact sciences with their stress upon quantities. And it did not enough recognize the reality of mind and of those human organizations and events for which mind is pivotal. In brief, past naturalism did not take evolution seriously nor did it take mind seriously. As we shall try to show in the course of our general argument, these two shortcomings are very closely connected. An

25. Sellars's position $(1918,1920,1961)$ differs from Hamilton's (6c), in that he does not regard the representative content as an object of perception (this point is less clear in Sellars [1916], which focuses on the negative case against naive realism). Sellars's analysis of perception was largely endorsed by Chisholm (1954), who balked at Sellars's materialism. Sellars's analysis is similar to Chisholm's (1957) theory of appearing or adverbial theory. The point is that the mental content in perception is not an entity, nor is it, as a modification of mind, normally the object of attention or of directed cognition. Sellars's position requires a cognitive act of affirmation to complete the perception of an external object, and in this way it is like Chisholm's (1957, chap. 1) propositional seeing; Chisholm (1957, chap. 10) also recognized a nonpropositional sense of seeing, consisting in an object's appropriately affecting the visual system in a way that makes the object appear some way to an observer. 
adequate naturalism must reckon without condescension with biology, psychology and sociology. $(1922,16)$

Past naturalism focused on the inorganic. ${ }^{26}$ Past epistemology focused on the need for the mind to be present to the immediate object of knowledge. In Sellars's critical realism and evolutionary naturalism, mind would be seen as an evolved capacity for knowing, as a functional process immersed "in" the organism as the living expression of its adjustment to its environment. As such, mind cannot confront the external object intuitively or presentatively; its knowledge is mediated by physiology and by mental content experienced as a state of the subject. But this mental content, in functioning to adjust the organism to its environment, takes external things as its object. Complete perceptual states are active referrings to external things. We intend, and attend to, the objects with which we interact.

Sellars's physicalism is an organic physicalism in which mind emerges from matter through the creative synthesis of evolution. His physicalized functionalism allowed him to address questions about knowledge and the mind-body problem in his own characteristic way. It was at its time a new position under the sun, one that acknowledged recent scientific advances but placed the results of science within a philosophy that looked out for itself.

\section{Conclusion}

In the introduction I sought to find a common link among a group of American philosophers in the first decades of the twentieth century that would comprise Pragmatists, New Realists, Critical Realists, and American Functionalists. I found this unity in a shared regard for evolution and biofunctional analysis. James and Sellars provided the main instances for analysis, but it would not be hard to show the presence of evolutionary and functional concerns in Dewey (1896), C. A. Strong (1903), and others. James, Sellars, and their compatriots are distinct in their uses of Darwin and functionalism because they brought the discussion prominently into the context of academic philosophy in America at a time when philosophical interest in the implications of Darwinian evolution had waned in Britain.

There is a deeper background that conditioned the new "realist" philosophies in both Britain and America: the conjunction of the problem of the

26. Strikingly, more than a decade later Schrödinger, Bohr, and Heisenberg made similar remarks about the exclusion of biological and psychological phenomena from the scientific outlook of nineteenth-century physics, on which see Hatfield (2009), 312-23. 
external world and the mind-body problem. The positions taken on these two problems define the various realisms of Moore and Russell, the New Realists, and the Critical Realists, and the mind-body problem provides a conditioning context for American Functionalism.

In the early decades of twentieth-century America, philosophy was undergoing rapid growth as many academies transitioned from colleges to research universities. Contrary to Daniel J. Wilson's (1990) story about American philosophers feeling "inferior" to scientists and suffering a crisis of consciousness, figures such as James, Sellars, Dewey, Woodbridge, and Strong were at home discussing traditional philosophical questions in metaphysics and epistemology in connection with Darwinian biology and various aspects of the new psychology. ${ }^{27}$ As Sellars put it, the recent successes of science raised new questions for philosophy but did not answer them. New scientific findings and conceptions invigorated American philosophy in the early decades of the twentieth century, a result that many philosophers welcomed.

\section{REFERENCES}

Alexander, Samuel. 1920. Space, Time, and Deity. 2 vols. London: Macmillan.

Angell, James Rowland. 1907. "The Province of Functional Psychology." Psychological Review 14:61-91.

Banks, Erik C. 2003. Ernst Mach's World Elements: A Study in Natural Philosophy. Dordrecht: Kluwer.

Bosanquet, Bernard. 1913. Review of Development and Purpose: An Essay towards a Philosophy of Evolution, by L. T. Hobhouse. Mind 22:383-87.

Burtt, Edwin A. 1925. The Metaphysical Foundations of Modern Physical Science: A Historical and Critical Essay. New York: Harcourt Brace \& Co.

Cambridge University. 1893. Calendar. Cambridge: Deighton, Bell.

Candlish, Stewart. 2007. The Russell/Bradley Dispute and Its Significance for TwentiethCentury Philosophy. Basingstoke: Macmillan.

Chisholm, Roderick M. 1954. "Sellars' Critical Realism." Philosophy and Phenomenolooical Research 15:33-47.

1957. Perceiving: A Philosophical Study. Ithaca, NY: Cornell University Press.

Clifford, W. K. 1874. "Body and Mind." Fortnightly Review, n.s., 16:714-36.

Cohen, Morris R. 1918. "Mechanism and Causality in Physics." Journal of Philosophy, Psycholoov and Scientific Methods 15:365-86.

Cunningham, Suzanne. 1996. Philosophy and the Darwinian Legacy. Rochester, NY: University of Rochester Press.

27. For further discussion of Wilson's thesis in relation to American philosophy and psychology in the early twentieth century, and also a comparison to the German situation, see Hatfield (2002). 
Darwin, Charles. 1859. On the Origin of Species by Means of Natural Selection. London: Murray.

Dewey, John. 1884. "The New Psychology." Andover Review 2:278-89.

— 1896. "The Reflex Arc Concept in Psychology." Psycholooical Review 3:357-70.

—, ed. 1903. Studies in Logical Theory. Chicago: University of Chicago Press.

- 1905. "The Realism of Pragmatism." Iournal of Philosophy. Psycholoov and Scientific Methods 2:324-27.

1910. The Influence of Darwin on Philosophy, and Other Essays in Contemporary Thought. New York: Holt.

Drake, Durant, ed. 1920. Essays in Critical Realism: A Co-operative Study of the Problem of Knowledge. London: Macmillan.

Foster, James J. S., ed. 2012. Scottish Philosophy in America. Exeter: Imprint Academic.

Hamilton, William. 1855. Discussions on Philosophy and Literature, Education and University Reform. New York: Harper. Original edition published in 1852.

- 1861. Lectures on Metaphysics. 2 vols. Edinburgh: Blackwood.

Hatfield, Gary. 2002. "Psychology, Philosophy, and Cognitive Science: Reflections on the History and Philosophy of Experimental Psychology." Mind and Lanouage 17:207-32.

—. 2009. "Sense Data and the Mind-Body Problem." In Perception and Cognition:

Essays in the Philosophy of Psychology, 297-321. Oxford: Clarendon.

- 2013a. "Perception and Sense Data." In Oxford Handbook of the History of Analytic Philosophy, ed. Michael Beaney, 948-74. Oxford: Oxford University Press.

— 2013b. "Psychology, Epistemology, and the Problem of the External World:

Russell and Before." In The Historic Turn in Analytic Philosophy, ed. Erich Reck, 171-200.

London: Macmillan.

Heidbredder, Edna. 1933. Seven Psychologies. New York: Appleton-Century-Crofts.

Hobhouse, L. T. 1896. Theory of Knowledge. London: Methuen.

-1901. Mind in Evolution. London: Macmillan.

-1906. Morals in Evolution: A Study in Comparative Ethics. London: Chapman \& Hall.

- 1913. Development and Purpose: An Essay towards a Philosophy of Evolution. London: Macmillan.

Holt, Edwin B., Walter T. Marvin, W. P. Montague, Ralph Barton Perry, Walter B. Pitkin, and Edward Gleason Spaulding. 1910. "The Program and First Platform of Six Realists." Lournal of Philosonhv, Psycholoov and Scientific Methods 7:393-401.

- 1912. The New Realism: Cooperative Studies in Philosophy. New York: Macmillan. Horstmann, Rolf-Peter. 1984. Ontologie und Relationen: Hegel, Bradley, Russell und die Kontroverse über interne und externe Beziehungen. Königstein: Athenäum Hain.

Huxley, T. H. 1874. "On the Hypothesis That Animals Are Automata, and Its History." Nature 10:362-66.

James, William. 1878. "Remarks on Spencer's Definition of Mind as Correspondence." Journal of Speculative Philosophy 12:1-18. 1890. Principles of Psychology. 2 vols. New York: Holt.

. 1904. "Does 'Consciousness' Exist?" Iournal of Philosothy, Psycholoov and Scientific Methods 1:477-91. 
1909. The Meaning of Truth. New York: Longmans, Green.

1912. Essays in Radical Empiricism. New York: Longmans, Green.

Kuklick, Bruce. 2001. A History of Philosophy in America, 1720-2000. Oxford: Clarendon. Lewes, George Henry. 1874-79. Problems of Life and Mind. 5 vols. London: Trübner.

Mach, Ernst. 1897. Contributions to the Analysis of the Sensations. Trans. C. M. Williams. Chicago: Open Court. Originally published as Beiträge zur Analyse der Empfindungen (Jena, 1886).

1976. Knowledge and Error: Sketches on the Psychology of Enquiry. Ed. Brian McGuinness. Dordrecht: Reidel. Translation of Erkenntnis und Irrtum, 5th ed. (Leipzig, 1926).

Menand, Louis. 2001. The Metaphysical Club. New York: Farrar, Straus \& Giroux.

Mill, John Stuart. 1872. Examination of Sir William Hamilton's Philosophy. London: Longman, Green, Reader, \& Dyer.

Montague, W. P. 1920-21. "Variation, Heredity and Consciousness." Proceedinos of the Aristotelian Society 21:13-50.

—. 1937. "The Story of American Realism." Philosophy 12:140-61.

Morgan, C. Lloyd. 1923. Emergent Evolution. New York: Holt.

Owens, D. Alfred, and Mark Wagner, eds. 1992. Progress in Modern Psychology: The Legacy of American Functionalism. Westport, CT: Praeger.

Perry, Ralph Barton. 1912. Present Philosophical Tendencies: A Critical Survey of Naturalism, Idealism, Pragmatism, and Realism, Together with a Synopsis of the Philosophy of William James. New York: Longmans, Green.

—. 1917. "Purpose as Tendency and Adaptation." Philosophical Review 26:477-95.

Reid, Thomas. 1846. Works. Ed. William Hamilton and Dugald Stewart. Edinburgh: Maclachlan \& Stewart.

1997. An Inquiry into the Human Mind: On the Principles of Common Sense. Ed.

Derek R. Brookes. University Park: Pennsylvania State University Press.

Richards, Robert J. 1987. Darwin and the Emergence of Evolutionary Theories of Mind and Behavior. Chicago: University of Chicago Press.

Ruckmich, C. A. 1913. "The Use of the Term Function in English Textbooks of Psychology." American Journal of Psycholoogy 24:99-123.

Russell, Bertrand. 1912. Problems of Philosophy. London: Williams \& Norgate.

. 1914. "On the Nature of Acquaintance: Preliminary Description of Experience." Monist 24:1-16.

1959. My Philosophical Development. New York: Simon \& Schuster.

Sellars, Roy Wood. 1907. "The Nature of Experience." Iournal of Philosophy, Psycholoov and Scientific Methods 4:14-18.

—. 1912. "Is There a Cognitive Relation?" Lournal of Philosophy, Psycholoov and Scientific Methods 9:225-32.

- 1916. Critical Realism. Chicago: Rand McNally.

. 1917. "The Status of Epistemology." Lournal of Philosophv, Psycholoov and Scientific

Methods 14:673-80. 
1918. "On the Nature of Our Knowledge of the Physical World." Philosophical Review 27:502-12.

- 1920. "Knowledge and Its Categories." In Drake 1920, 187-219.

1922. Evolutionary Naturalism. Chicago: Open Court.

1932. Philosophy of Physical Realism. New York: Macmillan.

1961. "Referential Transcendence." Philosophy and Phenomenolooical Research 22:

$1-15$.

1969. Reflections on American Philosophy from Within. Notre Dame, IN: University of Notre Dame Press.

Seth, James. 1908. Review of Morals in Evolution: A Study in Comparative Ethics, by L. T. Hobhouse. International Journal of Ethics 18:375-81.

Strong, Charles Augustus. 1903. Why the Mind Has a Body. New York: Macmillan.

Warren, W. Preston. 1970. “Introduction.” In Principles of Emergent Realism: Philosophical Essays by Roy Wood Sellars, xi-xx. St. Louis: Green.

Wiener, Philip P. 1949. Evolution and the Founders of Pragmatism. Cambridge, MA: Harvard University Press.

Wilson, Daniel J. 1990. Science, Community, and the Transformation of American Philosophy, 1860-1930. Chicago: University of Chicago Press.

Woodbridge, Frederick J. E. 1904. "The Field of Logic." Science, n.s., 20:587-600.

- 1908. Metaphysics. New York: Columbia University Press.

. 1912. "Evolution." Philosophical Review 2:137-51. 